\title{
ETV6 Gene
}

National Cancer Institute

\section{Source}

National Cancer Institute. ETV6 Gene. NCI Thesaurus. Code C18312.

This gene plays a regulatory role in transcription and in matrix metalloproteinase activity. 